Cornell Law Library Scholarship@Cornell Law: A Digital Repository

Cornell Law Faculty Publications

Faculty Scholarship

$5-5-2010$

\title{
Bobbleheads in Yale's Rare Book Collection!
}

Femi Cadmus

Cornell Law Library, fc276@cornell.edu

Follow this and additional works at: http://scholarship.law.cornell.edu/facpub

Part of the Library and Information Science Commons

\section{Recommended Citation}

Cadmus, Femi, "Bobbleheads in Yale's Rare Book Collection!" (2010). Cornell Law Faculty Publications. Paper 661.

http://scholarship.law.cornell.edu/facpub/661

This Article is brought to you for free and open access by the Faculty Scholarship at Scholarship@Cornell Law: A Digital Repository. It has been accepted for inclusion in Cornell Law Faculty Publications by an authorized administrator of Scholarship@Cornell Law: A Digital Repository. For more information, please contact jmp8@cornell.edu. 
Volume 26 No. I

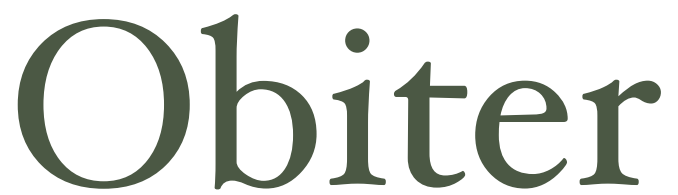

Saving Judicial Branch Law Libraries: The Present Crisis and Beyond

By Jonathan C. Stock

Over the last nineteen months, Connecticut experienced a unique challenge to its public law library system. Current economic conditions triggered Judicial Branch budget reductions that threatened closure of six among fifteen locations: $40 \%$ of all public access law libraries in this state. An extraordinary coalition arose supporting SNELLA in its effort to reverse a disastrous course: the American Association of Law Libraries, the Connecticut Bar Association, the Greater Bridgeport Bar Association, the Litchfield Bar Association, the Milford Bar Association, the New London County Bar Association, and the 1,145 private citizens who signed electronic petitions protesting these announced closings.

Testimony before two General Assembly Committees, Appropriations and Judiciary, helped forge a proposed bill designed to alleviate the problem as well as preventing its recurrence.

\section{Contents...}

Saving Judicial Branch Law Libraries................ I-6

Bobbleheads in Yale's Rare Book Collection..... ${ }^{-2} 2$

Message from the President..............................7

What's a Law Librarian To Do?........................8-I3, 22

WestlawNext.................................................14-16

SNELLA Spring Program.................................. 7

SNELLA Annual Dinner Announcement..........I8

SNELLA January Board Minutes....................... 9

Nominations...............................................2 $\mathrm{O}^{-2 \mathrm{I}}$

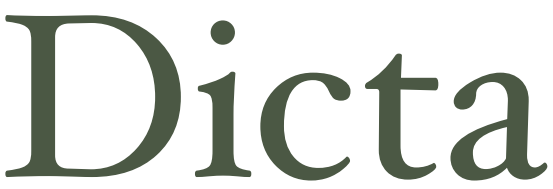

\section{Bobbleheads} in Yale's Rare Book Collection!

By Femi Cadmus

One of the interesting attributes of the Lillian Goldman Law Library at Yale Law

School is the ability to juxtapose the very serious and scholarly with the fun and whimsical.

So it was that in March

2009, the library became the official archive of Supreme Court Justices

Bobbleheads. The bobbleheads are a product of the GreenBag, An Entertaining Journal of the Law which on its website simply states "We make them for the joy of it..." The collection so far is comprised of seven modern day supreme court justices - the first, Chief justice William H. Rehnquist released in 2003 and the most recent, Justice David Souter released in 2009 (bobbleheads of two historic justices, 


\section{BOBBLEHEADS CONTINUED FROM PAGE I}

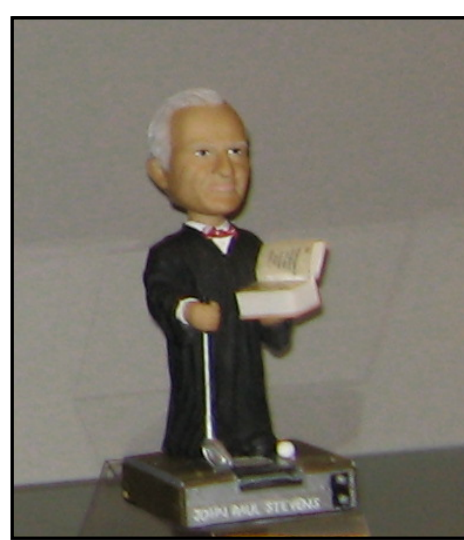

Justice John Paul Stevens

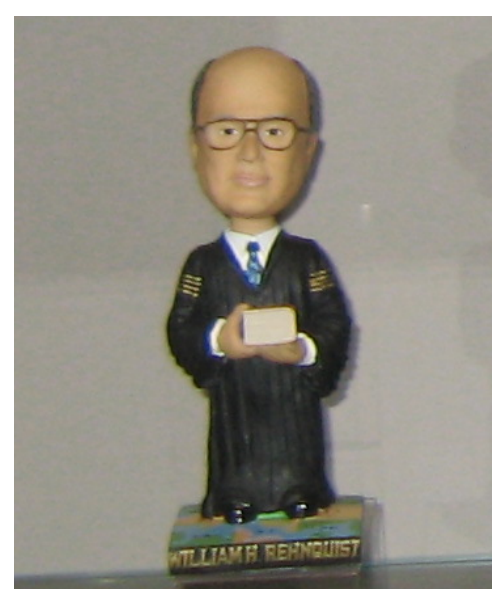

Justice William Rehnquist

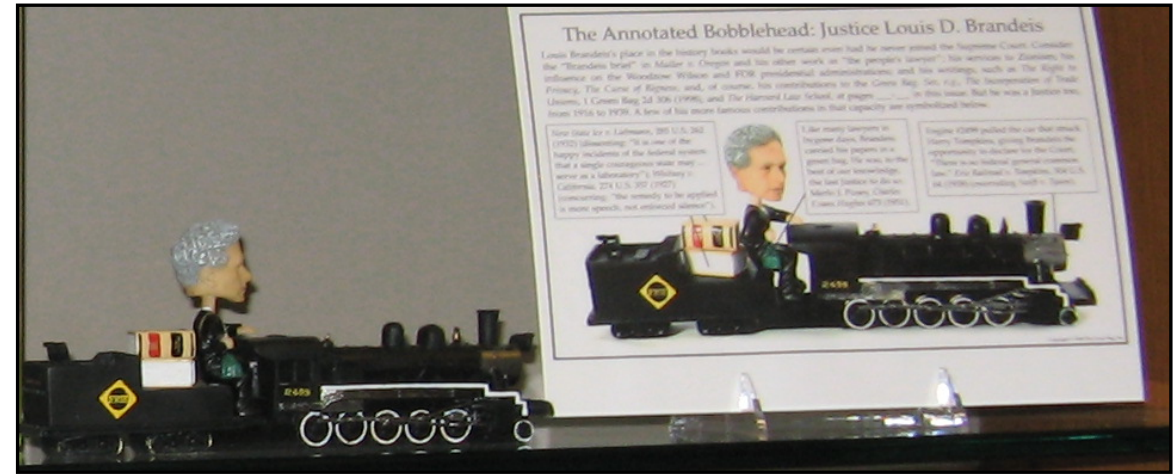

Justice Louis Brandeis

In addition, dozens of early and sometimes comically inaccurate early versions of bobbleheads and a beautiful, one-of- a-kind Scalia doll that was never put into production are housed in the collection. Fred Shapiro, Collections and access librarian soaked in the moment, stating that the bobbleheads "will now be archived for posterity and serve as a valuable resource to researchers in the future".

Since our rare books librarian Mike Widener, mounted the bobbleheads exhibit (next to another exhibit of Medieval Manuscript Fragments in Law Book Bindings), the library has had a steady flow of interested and curious observers. In the Fall another fun exhibit is coming - lawyers in comic books!

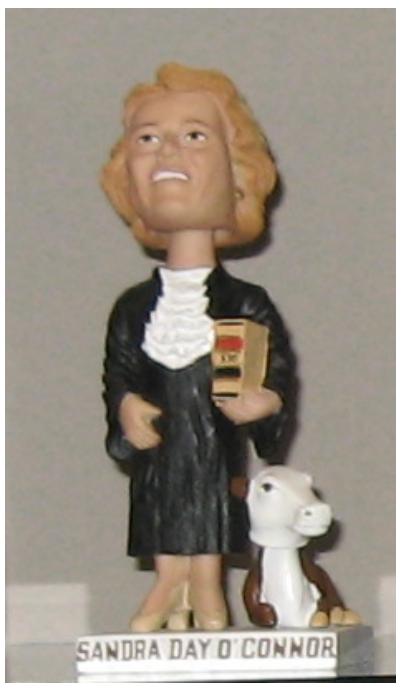

Justice Sandra Day O'Connor

\section{SAVING JUDICIAL BRANCH LAW LIBRARIES CONTINUED FROM PAGE I}

The proposal is currently traversing our legislative system; and, at this writing, its fate and final result remain ambiguous. However this drama plays out, one result already stands clear. We must vision beyond the present emergency; we must plan to insure that these events never transpire again. This article aims at starting the vision process in two distinct, but interlocking stages. One is narrating what happened; the second is suggesting why it happened.

Portraying what happened goes beyond narration. It also involves reading warning signals along the way: warning signals which, in retrospect, foreshadowed the impending crisis. Reading in retrospect acknowledges that no action on our part could have averted this crisis at the time. Economic forces were in play; and events moved fast, so fast that they became history before anyone could respond.

Continued on page 3 